\title{
KESALAHAN EJAAN DALAM SURAT PERMINTAAN KETERANGAN AHLI BAHASA DARI POLDA MALUKU UTARA
}

\author{
SPELLING ERRORS IN THE LETTER OF REQUEST FOR EXPERT \\ OPINION OF LANGUAGE EXPERTS FROM THE NORTH MALUKU \\ REGIONAL POLICE
}

Fida Febriningsih

Kantor Bahasa Maluku Utara

Jalan Raya Pertamina, Jambula, Pulau Ternate

Ponsel: 081355019689

\begin{abstract}
Abstrak
Penelitian ini bertujuan mengetahui kesalahan ejaan apa saja yang terdapat dalam Surat Permintaan Keterangan Ahli Bahasa dari Polda Maluku Utara dan memberikan rekomendasi perbaikan sebagai tambahan informasi bagi penulisan surat berikutnya. Penelitian ini menggunakan metode deskripsi dengan tiga tahapan, yaitu penyediaan data, analisis data, dan penyajian hasil analisis data. Sesuai hasil penelitian ditemukan empat jenis kesalahan ejaan, yaitu kesalahan penggunaan huruf, kesalahan penulisan kata, kesalahan pemakaian tanda baca, dan kesalahan penulisan unsur serapan.
\end{abstract}

Kata kunci: surat dinas, ejaan bahasa Indonesia, Surat Permintaan Ahli Bahasa

\begin{abstract}
The purpose of this study is to find out what spelling errors are contained in the Letter of Request for Expert Opinion of Language Experts from the North Maluku Regional Police and provide recommendations for improvements as additional information for writing the next letter. This study uses a description method with three stages, namely the stage of providing data, the data analysis phase, and the stage of presenting the results of data analysis. The results of the study found letters usage errors, word writing errors, punctuation usage errors, and absorption elements writing errors.
\end{abstract}

Keywords: official letter, Indonesian spelling, Letter of Request for Expert Opinion

\section{Pendahuluan}

Bahasa sangat penting bagi kehidupan manusia - sebagai alat komunikasi untuk menyampaikan ide, gagasan, dan pikiran dalam berinteraksi antara satu dan lainnya dalam kehidupan bermasyarakat, baik secara lisan maupun tulisan.

Surat adalah secarik kertas atau lebih yang berisi percakapan (bahasa komunikasi) yang disampaikan oleh seseorang kepada orang lain baik atas nama pribadi maupun organisasi/lembaga/instansi (Suryani, dkk., 2014). Komunikasi yang dilakukan dengan menggunakan media surat sampai saat ini masih relevan dan efektif, utamanya dalam komunikasi antarorganisasi/lembaga/instansi baik pemerintah maupun swasta. Selain sebagai alat komunikasi, surat memiliki fungsi sebagai dokumentasi tertulis, alat pengingat, bukti historis, pedoman bertindak, duta, jaminan keamanan, otak kegiatan kantor, dan barometer kemajuan kantor.-sebagai bahan kajian tentang aktivitasnya atau tindakantindakan yang pernah dilakukan selama beberapa tahun terakhir (Suprapto: 2006).

Masalah yang dikaji meliputi kesalahan ejaan yang terdapat dalam Surat Permintaan Keterangan Ahli Bahasa dari Kepolisian Daerah Maluku Utara, yang meliputi kesalahan penggunaan huruf, kesalahan 
penulisan kata, kesalahan pemakaian tanda baca, dan kesalahan penulisan unsur serapan.

Surat dinas, yaitu surat yang digunakan di lingkungan pemerintahan atau dinas-dinas pemerintah sebagai alat komunikasi dalam menjalankan kegiatan kedinasan. Dalam Kamus Besar Bahasa Indonesia, surat dinas bermakna surat yang dikeluarkan oleh kantor pemerintah atau instansi atau lembaga resmi lainnya dan bebas dari biaya.

Surat dinas isinya ditujukan untuk keperluan kedinasan, baik itu pemerintah atau swasta, karena fungsi kedinasan tidak hanya berlaku di pemerintahan, tetapi berlaku juga di instansi atau lembaga swasta. Biasanya, isinya berupa urusan, seperti penyampaian pengumuman, pemberian suatu izin, pemberian tugas, dan lain-lain.

Oleh karena itu, jika terdapat surat yang dikirimkan dari satu pihak ke pihak lain yang isinya berhubungan dengan kepentingan tugas ataupun kegiatan dinas suatu instansi, surat seperti itu disebut surat resmi. Mengapa disebut surat resmi? Hal tersebut dikarenakan penulisan dalam surat dinas ditulis dengan format tertentu dan memakai bahasa resmi.

Berikut beberapa prasyarat untuk membuat sebuah surat dinas.

1. Format dari surat harus teratur sesuai dengan format surat dinas.

2. Isi dari surat tidak terlalu panjang harus langsung pada inti yang ingin disampaikan.

3. Bahasa yang digunakan harus bahasa resmi, sopan dan mudah untuk dipahami pembaca.

4. Surat harus menggambarkan citra dari instansi atau lembaga yang membuatnya.

Surat dinas merupakan surat resmi dan tentu saja ada bagian-bagiannya. Sabariyanto (1998) menyebutkan surat terdiri atas beberapa bagian, yaitu (1) kepala surat, (2) tanggal surat, (3) nomor surat, (4)lampiran, (5) hal surat, (6) alamat surat, (7)salam pembuka, (8) isi, (9) salam penutup, (10) pengirim surat, (11) tembusan, dan (12) inisial.

Lebih lanjut, menurut Sabariyanto, jenis surat dinas, yaitu surat pengumuman, surat panggilan kerja, surat permohonan izin, surat undangan, surat pemberitahuan, surat pemberian izin, berita acara, surat keterangan, surat rekomendasi, surat keputusan, surat peringatan, surat bantahan, surat perintah, surat perjanjian kerja, surat laporan, surat pernyataan, surat pengantar, surat kuasa, surat perintah perjalanan dinas, surat pengusulan, surat perjanjian jual beli, dan surat perjanjian sewa-menyewa.

Bahasa surat adalah bahasa tulis, artinya bahasa dalam surat harus mengikuti kaidahkaidah yang berlaku-baku dan efektif. Kesalahan-kesalahan yang sering terjadi dalam penulisan surat dinas pada umumnya adalah penggunaan bahasa yang tidak baku. Kesalahan tersebut secara garis besar dapat dibagi dua, yaitu kesalahan dari segi ejaan dan segi tata bahasa. Kedua jenis kesalahan ini, untuk pembetulannya, sudah ada parameter/aturannya, yaitu Pedoman Umum Ejaan Bahasa Indonesia (PUEBI).

Untuk mengetahui apakah penggunaan suatu bentuk perilaku bahasa itu benar atau tidak dapat digunakan parameter yang mengacu kepada wujud bahasa yang taat terhadap kaidah-kaidah atau aturan kebahasaan yang berlaku. Oleh karena itu, kesalahan berbahasa adalah penggunaan bahasa, secara lisan maupun tertulis, yang berada di luar atau menyimpang dari kaidah kebahasaan dalam bahasa Indonesia. Kesalahan berbahasa adalah penggunaan bahasa yang menyimpang dari kaidah bahasa yang berlaku dalam bahasa itu. Sementara itu, kekeliruan adalah penggunaan bahasa yang menyimpang dari kaidah bahasa yang berlaku dalam bahasa, tetapi tidak dipandang sebagai suatu pelanggaran berbahasa karena sifatnya tidak acak, individual, tidak sistematis, dan tidak permanen (bersifat sementara). Jadi, analisis kesalahan berbahasa difokuskan pada kesalahan penggunaan ejaan. Terkait dengan kaidah, perlu adanya pengetahuan tentang Pedoman Umum Ejaan Bahasa Indonesia dan Tata Bahasa Baku Bahasa Indonesia.

Ejaan bahasa Indonesia selalu diperbarui dari tahun ke tahun. Sebelum PUEBI, kaidah pembakuan bahasa Indonesia mengacu pada ejaan bahasa Indonesia dikenal dengan Ejaan Bahasa Indonesia yang Disempurnakan (EYD). EYD merupakan ejaan yang 
diberlakukan di Republik Indonesia semenjak tahun 1972, menggantikan Ejaan Soewandi atau Ejaan Republik.

Ejaan bahasa Indonesia sudah direvisi sebanyak tiga kali, yaitu tahun 1987, 2009, dan 2015. Pokok penting dari pedoman ejaan terbaru atau dikenal dengan Pedoman Umum Ejaan Bahasa Indonesia (PUEBI) tahun 2015, yang di dalamnya dibahas tentang pemakaian huruf (huruf abjad, huruf vokal, huruf konsonan, huruf diftong, gabungan huruf konsonan, huruf kapital, huruf miring, dan shuruf tebal), penulisan kata (kata dasar, kata berimbuhan, bentuk ulang, gabungan kata, pemenggalan kata, kata depan, partikel, singkatan dan akronim, angka dan bilangan, kata ganti $k u-, k a u-,-k u,-m u$, dan -nya, kata $s i$ dan sang), pemakaian tanda baca (tanda titik, tanda koma, tanda titik koma, tanda titik dua, tanda hubung, tanda pisah, tanda tanya, tanda seru, tanda elipsis, tanda petik, tanda petik tunggal, tanda kurung, tanda kurung siku, tanda garis miring, dan tanda penyingkat atau apostrof), dan penulisan unsur serapan.

Dalam perkembangannya, bahasa Indonesia menyerap unsur dari berbagai bahasa, baik dari bahasa daerah, seperti bahasa Jawa, Sunda, dan Bali, maupun dari bahasa asing, seperti bahasa Sanskerta, Arab, Portugis, Belanda, Cina, dan Inggris. Berdasarkan taraf integrasinya, unsur serapan dalam bahasa Indonesia dapat dibagi menjadi dua kelompok besar. Pertama, unsur asing yang belum sepenuhnya terserap ke dalam bahasa Indonesia, seperti force majeur, de facto, de jure, dan l'exploitation de l'homme par l'homme. Unsur-unsur itu dipakai dalam konteks bahasa Indonesia, tetapi cara pengucapan dan penulisannya masih mengikuti cara asing. Kedua, unsur asing yang penulisan dan pengucapannya disesuaikan dengan kaidah bahasa Indonesia. Dalam hal ini, penyerapan diusahakan agar ejaannya diubah seperlunya sehingga bentuk Indonesianya masih dapat dibandingkan dengan bentuk asalnya.

Huruf kapital dipakai sebagai (1) huruf pertama kata pada awal kalimat, (2) huruf pertama petikan langsung, (3) huruf pertama dalam ungkapan yang berhubungan dengan nama, Tuhan dan kitab suci, termasuk kata ganti untuk Tuhan, (4) huruf pertama nama gelar kehormatan, keturunan, dan keagamaan yang diikuti nama orang, (5) huruf pertama unsur nama jabatan dan pangkat yang diikuti nama orang atau yang dipakai sebagai pengganti nama orang tertentu, nama instansi, atau nama tempat, (6) huruf pertama unsurunsur nama orang, (7) huruf pertama nama bangsa, suku bangsa, dan bahasa, (8) huruf pertama nama tahun, bulan, hari, hari raya, dan peristiwa sejarah, (9) huruf pertama nama geografi, (10) huruf pertama semua unsur nama negara, lembaga pemerintah dan ketatanegaraan, serta nama dokumen resmi kecuali kata seperti dan, (11) huruf pertama setiap unsur bentuk ulang sempurna yang terdapat pada nama badan, lembaga pemerintah dan ketatanegaraan, serta dokumen resmi, (12) huruf pertama semua kata (termasuk semua unsur kata ulang sempurna) di dalam nama buku, majalah, surat kabar, dan judul karangan, (13) huruf pertama unsur singkatan nama gelar, pangkat, dan sapaan, (14) huruf pertama kata penunjuk hubungan kekerabatan seperti bapak, ibu, saudara, kakak, adik, dan paman yang dipakai dalam penyapaan dan pengacuan, dan (15) huruf pertama kata ganti Anda.

Penulisan kata terbagi menjadi dua yaitu kata dasar dan kata turunan. Kata yang berupa kata dasar ditulis sebagai satu kesatuan. Sementara itu, penulisan kata turunan terbagi menjadi Imbuhan (awalan, sisipan, akhiran) ditulis serangkai dengan kata dasarnya, gabungan kata, bentuk ulang, kata ganti, dan kata depan. Kata depan $d i$, ke, dan dari ditulis terpisah dari kata yang mengikutinya kecuali di dalam gabungan kata yang sudah lazim dianggap sebagai satu kata seperti kepada dan daripada.

Singkatan ialah bentuk yang dipendekkan yang terdiri atas satu huruf atau lebih. Singkatan nama orang, nama gelar, sapaan, jabatan, atau pangkat diikuti dengan tanda titik. Singkatan nama resmi lembaga pemerintah dan ketatanegaraan, badan atau organisasi, serta nama dokumen resmi yang terdiri atas huruf awal kata ditulis dengan huruf kapital dan tidak diikuti dengan tanda 
titik. Singkatan umum yang terdiri atas tiga huruf atau lebih diikuti satu tanda titik. Akronim ialah singkatan yang berupa gabungan huruf awal, gabungan suku kata, ataupun gabungan huruf dan suku kata dari deret kata yang diperlakukan sebagai kata. Akronim nama diri yang berupa gabungan huruf awal dari deret kata ditulis seluruhnya dengan huruf kapital. Akronim nama diri yang berupa gabungan suku kata atau gabungan huruf dan suku kata dari deret kata ditulis dengan huruf awal huruf kapital. Akronim yang bukan nama diri yang berupa gabungan huruf, suku kata, ataupun gabungan huruf dan suku kata dari deret kata seluruhnya ditulis dengan huruf kecil.

\section{Metode}

Penelitian ini menggunakan metode deskripsi dengan tiga tahapan, yaitu penyediaan data, analisis data, dan penyajian hasil analisis data (Sudaryanto, 1993). Pengumpulan data menggunakan teknik simak dan teknik catat. Sumber data yang digunakan dalam penelitian ini adalah Surat Permintaan Keterangan Ahli Bahasa dari Kepolisian Daerah Maluku Utara yang ditujukan kepada Kepala Kantor Bahasa Maluku Utara pada tahun 2018.

Dalam tahap analisis data dilakukan langkah-langkah analisis kesalahan berbahasa dengan (1) membaca dan menelaah dokumen/surat dinas, (2) mengidentifikasi dan mencatat bentuk kesalahan, mengklasifikasi kesalahan, dan menjelaskan kesalahan.

Tahapan terakhir adalah penyajian hasil pengolahan data berupa hasil analisis data. Hasil analisis data disajikan secara informal dengan bahasa yang mudah dipahami.

\section{Hasil dan Pembahasan}

Pembahasan yang dilakukan dalam penelitian ini berdasarkan teori yang telah disajikan. Teori yang berhubungan dengan ejaan yang akan digunakan sebagai alat analisis adalah Pedoman Umum Ejaan Bahasa Indonesia. Pembahasan mengacu pada kesalahan ejaan apa saja yang terdapat dalam surat dan bagaimana evaluasinya berdasarkan PUEBI.

\subsection{Klasifikasi Data}

Data di dalam surat-surat tersebut yang telah di simak dan dicatat kesalahan penggunaan ejaannya kemudian diklasifikasikan. Berikut data-data yang telah dirangkum dalam tabel.

Tabel 1.

Surat Permintaan Keterangan Ahli Bahasa, Nomor B/278/IV/2017, tanggal 27 April 2017

\begin{tabular}{|l|l|}
\hline No. & \multicolumn{1}{|c|}{ Data } \\
\hline 1. & $\begin{array}{l}\text { Ternate.; ...AKBP SONNY, S.IK ...”; } \\
\text { lampiran: 1 ( satu ) berkas }\end{array}$ \\
\hline 2. & Perihal: Permintaan keterangan ahli \\
\hline 3. & $\begin{array}{l}\text { “..Kepala Kantor Bahasa Propinsi } \\
\text { Maluku Utara...” }\end{array}$ \\
\hline 4. & $\begin{array}{l}\text { Undang-Undang RI Nomor 2 Tahun 2002 } \\
\text { Tentang..” dan Surat perintah } \\
\text { Penyelidikan Nomor: } \\
\text { SP.Lidik/25/III/2017/Ditereskrimsus...”; }\end{array}$ \\
\hline 5. & Dilaksanakan pada : \\
\hline 6. & $\begin{array}{l}\text { Hari : Selasa } \\
\text { Tanggal: } 02 \text { Mei 2017 } \\
\text { Pukul : 10.00 Wit } \\
\text { Tempat: Ruang Subdit II... }\end{array}$ \\
\hline 7. & $\begin{array}{l}\text {... pidana dibidang Informasi dan } \\
\text { Transaksi Elektronik... }\end{array}$ \\
\hline 8. & “...handphone...” \\
\hline 9. & Iswarda Polda Malut \\
\hline
\end{tabular}

Tabel 2.

Surat Permintaan Keterangan Ahli Bahasa, Nomor B/190/III/2018, tanggal 15 Maret 2018

\begin{tabular}{|l|l|}
\hline No. & \multicolumn{1}{|c|}{ Data } \\
\hline 1. & $\begin{array}{l}\text { Ternate.. “...AKBP EDI SUGIARTO, } \\
\text { SE.,MH ...” }\end{array}$ \\
\hline 2. & $\begin{array}{l}\text { Perihal: Permohonan bantuan keterangan } \\
\text { ahli }\end{array}$ \\
\hline 3. & “....sebagaimana telah dirubah dengan...” \\
\hline 4. & ...terima kasih atas kerjasamanya \\
\hline 5. & $\begin{array}{l}\text { Undang-Undang RI Nomor 2 Tahun 2002 } \\
\text { Tentang..” }\end{array}$ \\
\hline 6. & $\begin{array}{l}\text { Hari : Senin } \\
\text { Tanggal: } 19 \text { Maret 2018 } \\
\text { Pukul : 09.00 Wit } \\
\text { Tempat : di ruang Subdit II...” }\end{array}$ \\
\hline 7. & $\begin{array}{l}\text { “... pidana dibidang Informasi dan } \\
\text { Transaksi Elektronik...”; ....dengan } \\
\text { rujukan tersebut diatas,...”; }\end{array}$ \\
\hline 8. & “...Hp...” \\
\hline 9. & Iswarda Polda Malut; \\
\hline
\end{tabular}

Tabel 3.

Surat Permintaan Keterangan Ahli Bahasa, Nomor B/199/III/2018, tanggal 20 Maret 2018 \begin{tabular}{|l|l}
\hline No. & Data \\
\hline
\end{tabular} 


\begin{tabular}{|l|l|}
\hline 1. & $\begin{array}{l}\text { Ternate..“...AKBP EDI SUGIARTO, } \\
\text { SE.,MH ...” }\end{array}$ \\
\hline 2. & $\begin{array}{l}\text { Perihal; Permohonan bantuan keterangan } \\
\text { ahli }\end{array}$ \\
\hline 3. & terima kasih atas kerjasamnya \\
\hline 4. & $\begin{array}{l}\text { Undang-Undang RI Nomor 2 Tahun 2002 } \\
\text { Tentang..” }\end{array}$ \\
\hline 5. & $\begin{array}{l}\text { Hari : Senin } \\
\text { Tanggal: 26 Maret 2018 } \\
\text { Pukul : 09.00 Wit } \\
\text { Tempat: di ruang Subdit II...” }\end{array}$ \\
\hline 6. & $\begin{array}{l}\text { "... pidana dibidang Informasi dan } \\
\text { Transaksi Elektronik...”; ...dengan } \\
\text { rujukan tersebut diatas,...”; }\end{array}$ \\
\hline 7. & "...Hp...” \\
\hline 8. & Iswarda Polda Malut; \\
\hline
\end{tabular}

Tabel 4.

Surat Permintaan Keterangan Ahli Bahasa, Nomor B/191/III/2018, tanggal 15 Maret 2018

\begin{tabular}{|l|l|}
\hline No. & \multicolumn{1}{|c|}{ Data } \\
\hline 1. & $\begin{array}{l}\text { Ternate..“...AKBP EDI SUGIARTO, } \\
\text { SE.,MH ...”; Masrur, S. H. S.IK...”; } \\
\text { “...(setiap orang dengan sengaja...” }\end{array}$ \\
\hline 2. & $\begin{array}{l}\text { Perihal: Permohonan bantuan keterangan } \\
\text { ahli }\end{array}$ \\
\hline 3. & terima kasih atas kerjasamanya \\
\hline 4. & “...sebagaimana telah dirubah dengan...” \\
\hline 5. & $\begin{array}{l}\text { Undang.Undang RI Nomor 2 Tahun 2002 } \\
\text { Tentang..”; “...keterangan selaku Ahli...” }\end{array}$ \\
\hline 6. & $\begin{array}{l}\text { Hari : Rabu } \\
\text { Tanggal: 21 Maret 2018 } \\
\text { Pukul : 09.00 Wit } \\
\text { Tempat: di ruang Subdit II....” }\end{array}$ \\
\hline 7. & $\begin{array}{l}\text { “...pidana dibidang Informasi dan } \\
\text { Transaksi Elektronik...”; ...perkara } \\
\text { tersebut diatas,...”; “...memiliki keahlian } \\
\text { dibidang...” }\end{array}$ \\
\hline 8. & “...Hp...” \\
\hline 9. & Iswarda Polda Malut; \\
\hline
\end{tabular}

\subsection{Analisis Kesalahan Penggunaan Ejaan}

Berdasarkan klasifikasi data, selanjutnya dilakukan analisis data. Dari hasil analisis data, kesalahan ejaan yang banyak ditemukan dalam Surat Permintaan Keterangan Ahli Bahasa tersebut, yaitu kesalahan penggunaan huruf, kesalahan penulisan kata, kesalahan pemakaian tanda baca, dan kesalahan penulisan unsur serapan.

\subsubsection{Kesalahan Penggunaan Huruf}

Huruf kapital dipakai sebagai huruf pertama semua kata(termasuk semua unsur bentuk ulang sempurna) dalam nama negara, lembaga, badan, organisasi, atau dokumen, kecuali kata tugas, seperti di, ke, dari, dan, yang, dan untuk.

Kesalahan penggunaan huruf kapital terdapat pada surat dalam Tabel 1 (No. 4). Surat perintah penyelidikan merupakan nama dokumen maka harus menggunakan huruf kapital di setiap unsurnya. Pada Tabel 1 (No. 6), Tabel 2 (No. 6), Tabel 3 (No. 5), dan Tabel 4 (No. 6) uraian hari, tanggal, pukul, dan tempat tidak diawali dengan huruf kapital karena merupakan uraian unsur dari kalimat sebelumnya, yaitu dilaksanakan pada: Selain itu, kata 'ruang Subdit' pada Tabel 2 (No. 6), Tabel 3 (No. 5) dan Tabel 4 (No. 6) harus menggunakan huruf kapital di awal kata karena merupakan nama tempat.

Rekomendasi perbaikan:

Tabel 1 (No. 4)

Undang-Undang RI Nomor 2 Tahun 2002 tentang..." dan Surat Perintah Penyelidikan Nomor SP.Lidik/25/III/2017/Diterskrimsus...

Tabel 1 (No. 6)

hari: Selasa

tanggal : 02 Mei 2017

pukul : $10.00 \mathrm{WIT}$

tempat : Ruang Subdit II.

Tabel 2 (No. 6)

hari: Senin

tanggal : 19 Maret 2018

pukul : 09.00 WIT

tempat : di Ruang Subdit II.

Tabel 3 (No. 5)

hari: Senin

tanggal : 26 Maret 2018

pukul : $09.00 \mathrm{WIT}$

tempat : di Ruang Subdit II.

Tabel 4 (No. 6)

hari: Rabu

tanggal : 21 Maret 2018

pukul : $09.00 \mathrm{Wit}$

tempat : di Ruang Subdit II...” 


\subsubsection{Kesalahan Penulisan Kata}

Kesalahan penulisan kata terdapat pada Tabel 1 (No. 6), Tabel 2 (No. 6), Tabel 3 (No. 5) dan Tabel 4 (No. 6), yaitu singkatan "Waktu Indonesia Timur" pada kalimat "pukul: .....Wit" harus ditulis dengan huruf kapital tanpa tanda titik karena terdiri atas huruf awal setiap kata yang bukan nama diri. Selain itu, kesalahan penulisan singkatan juga terdapat pada Tabel 1 (No. 1) ...AKBP SONNY, S.IK ..."; Tabel 2 (No. 1) AKBP EDI SUGIARTO, SE.,MH; Tabel 3 (No. 1) AKBP EDI SUGIARTO, SE.,MH; dan Tabel 4 (No. 1) AKBP EDI SUGIARTO, SE.,MH ...”; Masrur, S. H. S.IK. Singkatan nama orang, gelar, sapaan, jabatan, atau pangkat diikuti dengan tanda titik pada setiap unsur singkatan itu. Selain itu, kesalahan penulisan singkatan juga terdapat pada Tabel 2 (No. 8), Tabel 3 (No. 7), dan Tabel 4 (No. 8), yaitu kata “...Hp...” yang seharusnya ditulis 'Ponsel atau HP'.

Pada Tabel 2 (No. 3) dan Tabel 3 (No. 3), terdapat kesalahan penggunaan kata berimbuhan 'dirubah' seharusnya 'diubah' karena berasal dari kata dasar 'ubah' yang mendapat awalan di. Tabel 2 (No. 4), dan Tabel 4 (No. 3) terdapat kesalahan penulisan gabungan kata 'kerjasamanya' seharusnya 'kerja samanya' karena gabungan kata yang penulisannya terpisah tetap ditulis terpisah jika mendapat awalan atau akhiran.

Pada Tabel 1 (No. 7), Tabel 2 (No. 7), Tabel 3 (No. 6), dan Tabel 4 (No. 7), terdapat kesalahan penulisan kata depan $d i$ - yang ditulis serangkai dengan kata yang mengikutinya, yaitu kata 'dibidang' dan 'diatas' yang seharusnya ditulis terpisah menjadi 'di bidang' dan 'di atas' karena kata depan, seperti di, ke, dan dari, ditulis terpisah dari kata yang mengikutinya.

Rekomendasi perbaikan:

Tebel 1 (No. 6), Tabel 2 (No. 6), Tabel 3 (No. 5), dan Tabel 4 (No. 6)

pukul: ......... WIT

Tabel 1 (No. 1) AKBP SONNY, S.I.K.; Tabel 2 (No. 1) AKBP EDI SUGIARTO, S.E.,M.H.;
Tabel 3 (No. 1) AKBP EDI SUGIARTO,

S.E.,M.H.; dan

Tabel 4 (No. 1) AKBP EDI SUGIARTO,

S.E.,M.H. .

Masrur, S.H., S.I.K.

Tabel 2 (No. 3) dan Tabel 3 (No. 3):

.... diubah....

Tabel 2 (No. 4) dan Tabel 4 (No. 3):

......kerja samanya....

Tabel 1 (No. 7), Tabel 2 (No. 7), Tabel 3 (No. 6), dan Tabel 4 (No. 7):

“... pidana dibidang Informasi dan Transaksi Elektronik..."; '...dengan rujukan tersebut di atas,...";

\subsubsection{Kesalahan Pemakaian Tanda Baca}

Kesalahan pemakaian tanda baca terdapat pada Tabel 1 (No. 4), Tabel 2 (No. 4), Tabel 3 (No. 4), dan Tabel 4 (No. d), yaitu penggunaan garis bawah pada perihal surat tidak perlu menggunakan garis bawah karena garis bawah digunakan pada bagian yang akan dicetak miring pada mesin tik atau tulisan tangan. Begitu juga dengan bagian dari tembusan pada Tabel 1 (No. 9), Tabel 2 (No. 9), Tabel 3 (No. 8), dan Tabel 4 (No. 9), yaitu Iswarda Polda Malut dan tidak perlu menggunakan garis bawah. Kesalahan pemakaian garis bawah juga terdapat pada Tabel 1 (No. 1), Tabel 2 (No. 1), Tabel 3 (No. 1), dan Tabel 4 (No. 1), yaitu pada alamat tujuan surat 'Ternate'. Seharusnya 'Ternate' saja dan tidak perlu menggunakan garis bawah.

Rekomendasi perbaikan:

Tabel 1 (No. 4), Tabel 2 (No. 4), Tabel 3 (No. 4), Tabel 4 (No. 4):

Perihal: Permohonan bantuan keterangan ahli

Tabel 1 (No. 9), Tabel 2 (No. 9), Tabel 3 (No. 8), dan Tabel 4 (No. 9):

Iswarda Polda Malut

Tabel 1 (No. 1), Tabel 2 (No. 1), Tabel 3 (No. 1), dan Tabel 4 (No. 1):

Ternate.

\subsubsection{Kesalahan Penulisan Unsur Serapan}

Kesalahan penulisan bentuk serapan terdapat pada Tabel 1 (No. 8) "...handphone..." sudah diserap ke dalam bahasa Indonesia menjadi 
telepon genggam. Jika ingin tetap menggunakan bahasa Inggris, penulisannya harus dimiringkan menjadi handphone atau menggunakan kata "ponsel”.

\section{Simpulan}

Berdasarkan hasil pembahasan dan analisis data, beberapa kesalahan ejaan ditemukan dalam Surat Permintaan Keterangan Ahli Bahasa dari Kepolisian Daerah Maluku Utara, yaitu kesalahan penggunaan huruf, kesalahan penulisan kata, kesalahan pemakaian tanda baca, dan kesalahan penulisan unsur serapan.

Penelitian tentang kesalahan penggunaan ejaan dalam surat dinas perlu dilakukan sebagai rekomendasi perbaikan bagi penulisan surat berikutnya agar bahasa surat lebih jelas dan tidak menimbulkan kesalahpahaman. Penelitian lanjutan yang terstruktur sangat dibutuhkan sebagai bank data dan referensi tambahan bagi penelitian selanjutnya.

\section{Daftar Pustaka}

Alwi, Hasan.et al. (1993). Tata Bahasa Baku Bahasa Indonesia. Jakarta: Balai Pustaka.

Kridalaksana, Harimurti. (2007). Kamus Linguistik. Edisi ketiga. Jakarta: Gramedia Pustaka Utama

Mahsun. (2007). Metode Penelitian Bahasa (Tahapan, Strategi, Metode, dan Tekniknya). Jakarta: Raja Grafindo Persada.

Matanggui, Junaiyah dan Zaenal Arifin. (2015). Analisis Kesalahan Berbahasa Indonesia. Tangerang: Pustaka Mandiri.

Peraturan Menteri Pendidikan dan Kebudayaan Republik Indonesia Nomor 50 Tahun 2015 tentang Pedoman Umum Ejaan Bahasa Indonesia.

Sabaryanto, Dirgo. (1998). Bahasa Surat Dinas. Yogyakarta: Mitra Gama Widya.

Sudaryanto, (1993). Metode dan Aneka Teknik Analisis Bahasa. Yogyakarta: MLI Komsariat Universitas Gajah Mada.

Suprapto. (2014). Penuntun Praktis Surat Menyurat Dinas Resmi Bahasa Indonesia. Bandung: Mandar Maju.
Suryani, Nanik, dkk. (2014). Korespondensi Bahasa Indonesia. Yogyakarta: Graha Ilmu. 